\title{
The Use of the Makassar Dialect of Indonesian in the Native Speakers in the Gowa District
}

\begin{abstract}
Asriani Abbas
Cultural sciences Faculty, Hasanuddin University

Email: asriani.abbas@unhas.ac.id

ABSTRACT

Makassarese speakers are bilingual. They are generally domiciled in the southern part of South Sulawesi Province, especially in Gowa Regency. The alternation of Makassarese and Indonesian languages has the consequence of mutual influence at various levels, including the morphological level. This study aims to describe the form of words and the meaning carried by each word due to the morphological influence of the Makassar language on the Indonesian language. This research is a type of descriptive research. Sources of data are the speeches of respondents who live in Gowa Regency as twenty people who were selected purposively based on occupation (employees, teachers, traders, and students); age (between 18-47 years); and education (junior till high school). The data were analyzed according to the properties of the morphemes and then transcribed according to their basic forms. The results showed that the morphological influence of the Makassar language into Indonesian has certain characteristics, namely the presence of a bound element in the form of clitics. There are clitics in the form of personal pronouns; some are in the form of particles. Clitics derived from personal pronouns consist of neutral or familiar pronouns and honorific or polite pronouns. There are clitics in the form of particles that function as affirmations while others act as markers of time or time. These clitics can be attached to the class of nouns, verbs, adjectives, numerals by carrying different meanings according to the context of the speech.
\end{abstract}

Keywords: Makassar language, Indonesia language, morphological influence.

\section{INTRODUCTION}

Makassar language is also known as 'bicara Mangkasara' which is spoken by the Makassarese people in the southern part of South Sulawesi Province, including in Gowa Regency. The language has its alphabet called 'Lontarak' which is used as the language of ethnic group, the language of culture, the language of religion, and the language of education. It is also used in oral literary traditions, such as kelong-kelong, lontarak paupau, others.

Gowa Regency is inhabited by multiethnic people who come from various regions such as Bugis, Javanese, Toraja, Bima, Sumbawa, and so on. These ethnic differences also have consequences for the language differences between speakers. However, speakers of different ethnicities seem to be submissive to the local language, namely the Makassar language. The difference in language background makes them switch codes using Indonesian as inter-ethnic glue. The mastery of the Makassar language and Indonesian language alternately by the people who live in Gowa Regency can lead to language contact. Spolsky [1] states that a language contact is an event of mutual influence between one language and another. Language contact, as stated by Suwito [2] can occur in bilingual communities that use two languages interchangeably. There are morphological symptoms that occur due to the contact between the Makassar language and the Indonesian language. Makassar language clitics have been identified that affect Indonesian with various classes of words that can be attached to them. Likewise, the presence of clitics carries different meanings according to the context of its use.

The Makassar people, known as the Makassar ethnic group are a group of people who inhabit the area on the west coast of the South Sulawesi peninsula which includes the regencies of Gowa, Takalar, Jeneponto, Bantaeng, Maros, Pangkajene Islands, Selayar, and Makassar city. Makassar language speakers are people who master the Makassar language as their first language and use the language in their daily interactions [3].

In the speech community, they already have elements of a common life that causes a relationship of mutual influence between parties. Davies [4] states that 
the elements of togetherness in question include: attitude (manners), custom (custom), tradition (tradition), and ways of speaking (modes of speaking). In this case, the image of Makassar society as a group of people living together for generations shows the existence of traditional elements. The elements that build a word include clitics. The term clitics come from the Greek klinien 'lean', namely short words that rely on the basic form can be categorized as clitics by Verhaar [5]

In addition to clitics, there are also time markers which refer to something about the time of a verb concerning the time it is uttered. This includes past (perfective), present (presentive), and future (futuristic) categories. The past tense occurs in a period that includes before the utterance, the present tense occurs during the utterance, and the future tense occurs after the utterance. In the Makassar language, there are also markers of time - $p a$ (futuristic), - $m a$ (perfective), and ja (presentive), [6].

\section{METHODOLOGY}

This research is a type of descriptive research. The source of the data is the speech of respondents who live in the Gowa Regency. Twenty respondents were selected purposively based on occupation, age, and education.

Data collection uses the listening method, namely listening to the respondent's speech which is built by words that have undergone a morphological process. The listening method includes tapping techniques, listening to conversations, recording, and taking notes. In addition, a conversational engagement technique is also applied. Next, the recording is done. In addition to recording, note-taking techniques are also used. The data were analyzed descriptively according to the properties of the morphemes. After that, the data was transcribed according to its basic forms to find out the clitics attached to the basic morpheme and the word classes that could be attached to it.

\section{ANALYSIS}

\subsection{The Use of Indonesian Makassar Dialect among the Speaking Communities in Gowa Regency}

\subsubsection{Personal Pronoun I}

Persona pronoun I in the Makassar language consists of the singular I pronoun nakke 'I' can turn into proclitic in the form of $k u$ - 'ku-' and becomes enclitic in the form of $-a k$ 'I'. Furthermore, the personal pronoun I plural katté 'we/us' can change into proclitic in the $\mathrm{ki}$ 'you/lord' form and into enclitic in the $k i$ - 'you/lord' form.
Singular Personal Pronoun I in the form of proclitic $k u$ - 'ku-'

(1) Ku-simpang-i buku-nu. 'I put your book'.

pro enk enk

In sentence (1) there are three forms of clitics, namely: proclitic $k u$-, enclitic $-i$, and enclitic $-n u$. The proclitic $k u$ - 'ku-' which is attached to the verb save gives the meaning that person I does the activity of keeping books. Meanwhile, the $-i$ enclitic attached to the verb functions as an absolute marker which refers exophorically to your book 'your book'. Enclitic -nu 'mu' attached to the book noun states ownership (possessive).

Singular Personal Pronoun I in the form of enclitic $a k$ 'saya'

(2) Makang-ak pisang goreng di kantin tadi. 'I ate fried banana in the canteen.' prok

The enclitic $a k$ - 'I-' in the sentence (2) which is attached to the verb eating means that person I did the activity of eating fried bananas in the canteen earlier.

\subsubsection{Personal Pronoun II}

Persona pronoun II in the Makassar language consists of personal pronouns II $\mathrm{kau}$ 'you' which can turn into proclitics in the form of $n u$ - 'kau-' which is familiar and $\mathrm{ki}^{-}$'anda/lord' which is honorific (takzim).

Familiar Personal Pronoun II in the form of proclitic $n u$ - 'kau-'

(3) Nu-baca-i berita-na? 'Do you read the news?' prok enk enk

In sentence (3) there are three forms of clitics, namely: proclitic $n u-$, enclitic $-i$, and enclitic -na. The proclitic $n u$ - 'kau-' attached to the verb read means that the questioner wants to get an answer about the news that has been read by his interlocutor. Meanwhile, the $-i$ enclitic in the verb functions as an absolute marker referring exophorically to the news.

Honorific Personal Pronoun II in the form of proclitic $k i$ - 'you/lord'

(4) Ki-undang-i teman -ta! 'Please lord invites your friends.'

Prok enk

enk

In sentence (4) there are three forms of clitics, namely: proclitic $k i$ - 'your/lord', enclitic $-i$ 'he', and enclitic - $t a$ 'your/yours'. The proclitic $k i$ - 'you/lord' attached to the legal verb means that the questioner wants to ask his interlocutor to invite his friends. Meanwhile, the enclitic $-i$ in the verb functions as an absolute marker referring exophorically to his friend.

Persona II enclitic distinguishes between the familiar form of $-k o$ 'you' and $-k i$ 'your/lord' which is honorific 
(takzim). It can also be in the possessive form - $n u$ 'your' and $-t a$ 'your/lord'.

Personal Pronoun II in the form of enclitic -ko 'you'

(5) Mau-ko ke mana? 'Where do you go?' enk

Enclitic - $k o$ 'you-' in the sentence (5) which is attached to the verb want to give the meaning that the questioner wants to get an answer about where the interlocutor will go. The -ko 'you' greeting indicates that an interlocutor is a younger person or of the same age as the speaker.

Honorific Personal Pronoun II in the form of enclitic $-k i$ 'your/lord'

(6) Mau-ki ke mana? 'Where will lord go?' enk

Enclitic $-k i$ 'you/lord' in the sentence (6) which is attached to the verb wants to give the meaning that the questioner wants to get an answer about where the interlocutor is going. Familiar and honorific personal pronouns are generally used to express orders/requests.

Familiar Personal Pronoun II in the form of enclitic $n u$ 'posesif'

(7) Mana buku-nu? 'Where is your book?' Enk

Enclitic - $n u$ 'yours' as a familiar greeting in the sentence (7) attached to the book noun means that the questioner wants to get an answer about where the book belongs to the interlocutor.

(8) Mana buku-ta? 'Where is your book?'

Enk

The enclitic - $t a$ 'yours/sir' as an honorific greeting in the sentence (8) attached to the book noun means that the questioner wants to get an answer about where the book belongs to his interlocutor.

\subsubsection{Personal Pronoun III}

Persona pronoun III in the Makassar language consists of the singular persona pronoun ia 'he' can turn into proclitics in the form of $n a$ - 'he' and becomes enclitic in the form of $-i$ 'he'. 'dia

Pronomina persona III dalam bentuk proklitika $n a$ -

(9) Na-ambil-ki buku-ku di kantor-na. 'He takes my book in his office.'

prok enk enk enk

The proclitic na- 'he-' in the sentence (9) is attached to the verb take. Meanwhile, enclitic $-i$ functions as an absolute marker referring exophorically to bukuku 'my book'.

(10) Dingin-na hawaya tidak terasa lagi. 'I can't feel the cold anymore." enk

The enclitic na- 'nya' in the sentence (10) is attached to an adjective of cold. Meanwhile, the determinative marker -ya 'that' in the noun air situation as a determinant refers exophorically to the state of the air.

\subsection{The Enclitic as The Marker of Time}

3.2.1 Enclitics -ma as a time marker can be integrated into -mak, -mako, -maki, and-mi.

The enclitics can contain the meaning of work that has been going on.

(11) Makanmak 'I have eaten.'

The marker time of $m a$ - joins the personal pronoun I $-a k$ to become -mak gives the meaning that the eating activity has been carried out by the person I.

Pergimak 'I have gone.'

Belajarmak 'I have learned.'

(12) Makanmako? 'Have you eaten??'

The marker time of $m a$ - joins the familiar persona pronoun II -ko becomes -mako. The time marker attached to the word 'eat' gives the meaning of seriousness to know that it is true that person II has done eating activities.

(13) Makanmako! 'Please eating!'

The marker time of $m a$ - which joins the familiar personal pronoun II - $k o$ becomes - mako the word attached to the word 'eat' gives the meaning of asking person II to do eating activities.

(14) Makanmaki? 'Have you eaten, sir?'

The marker time of $m a$ - which joins the honorific second persona pronoun - $k i$ becomes -maki the word attached to the word 'eat' gives the meaning of affirmation to know that it is true that person II is doing the eating activity.

(15) Makanmaki! 'Please you are eating, sir!'

The marker time of ma- which joins the honorific persona pronoun II - $k i$ becomes -maki the word attached to the word 'eat' gives the meaning of asking person II to do now the activity of eating.

Pergimaki! 'Please you are going to, sir!' Belajarmaki! 'Please you are learning, sir!'

(16) Makanmi. 'Dia sudah makan.'

Pemarkah kala ma- yang bergabung dengan pronomina persona III -i menjadi -mi memberikan makna bahwa aktivitas makan sudah dilakukan oleh orang III. The marker time of $m a$ - which joins the persona pronoun III $i$ to become - $m i$ gives the meaning that the eating activity has been carried out by person III

Pergimi. 'He has gone.' 


\section{(17) Makanmi! 'Please eating it.'}

The marker time of $m a$ - which joins the honorific third persona pronoun $-i$ become $-m i$ which is attached to the word 'eat' can mean inviting people to eat something.

Enclitic -ja can integrate becoming -jak, -jako, -jaki, dan -ji. Those enclitics can contain the meaning of seriousness in the present form (work in progress).

(18) Makanjak. 'That's right I ate.'

The marker of time -ja which joins the personal pronoun I - ak to become -jak gives the meaning to know that the work of 'eating' is done by person I.

(19) Makanjako? 'Are you right eating?'

The markers of time -ja which are joined with the familiar persona pronoun II -ko to become -jako which is attached to the word 'eat' give the meaning of seriousness to know that it is true that person II is doing the activity of 'eating'.

(20) Makanjaki? 'Are you eating right, sir?'

The marker of time $-j a$ which joins the honorific $-k i$ persona II becomes - maki the word attached to the word 'eating' gives the meaning of seriousness to know that it is true person II is doing the activity 'eating'.

Are you right going, please?'

Are you right learning, please?'

(21) Makanjaki. 'Please your are eating, sir!'

The marker of time ma- which joins the honorific persona pronoun II - $k i$ becomes -maki the word attached to the word 'eat' gives the meaning of asking person II to do eating activities.

Pergimaki! 'Please you are going on, sir!'

Belajarmaki! 'Please you are learning, sir!'

(22) Makanji. 'He really is eating.'

The marker of time $j a$ - which joins the pronouns of persona III $-i$ to become $-j i$ gives the meaning that the eating activity is being carried out by person III.

Pergiji. 'He really is going on.'

Belajarji. 'He really is learning.'

(23) Makanji? 'Is he really going on?'

The marker of time $j a$ - which joins the pronouns of persona III $-i$ to become $-j i$ attached to the word 'eat' gives a reinforcing meaning that person III is indeed doing eating activities.

Pergiji? 'Is he right going on?'

Belajarji? 'Is he right learning?'

\subsubsection{The enclitics -pak, -pako, -paki, and -pi can contain the meaning of the work to be done}

The enclitics can contain the meaning of work that the work will be done.
(24) Makanpak. 'Later when I eat.'

The marker of time $p a$ - which joins the personal pronoun I $-a k$ becomes $-p a k$ gives the meaning of the work that will be carried out by person I.

Pergipak 'Later if I go.'

Belajarpak 'Later if I learn.'

(25) Makanpako? 'Later when do you eat?'

The marker of time $p a$ - which joins the familiar personal pronoun II -ko becomes - pako which is attached to the word 'eat' gives the meaning of eating activities that will know what person II will do.

Pergipako? 'Later if do you go?'

Belajarpako? 'Later if you learn?'

(26) Makanpaki? 'Later when do you eat, sir?'

The marker of time $p a$ - which joins the honorific second personal pronoun - $k i$ becomes -paki which is attached to the word 'eat' gives the meaning that the eating activity will be carried out by person II.

Pergipaki?' 'Later if do you go, sir?'

Belajarpaki?' Later if do you learn, sir?'

(27) Makanpaki. 'Later when you eat, sir.'

The marker of time $p a$ - which joins the honorific personal pronoun II - pi becomes -paki which is attached to the word 'eat' gives the meaning that the eating activity will be carried out by person II.

Pergipaki. 'Later if you go, sir.'

Belajarpaki! 'Later if you learn, sir.'

(28) Makanpi. 'Nanti kalau dia makan.'

The marker of time $p a$ - which joins the pronouns of persona III $-i$ becomes -pi gives the meaning that the eating activity will be carried out by person III.

\section{CONCLUSION}

Makassar language can consist of one word at the same time as a sentence. The sentence is built by clitics and markers of time. Even with aspect markers. Based on the linguistic facts that have been identified and classified, it can be seen that the morphological influence of Makassar language into Indonesian has certain characteristics, namely the presence of a bound element in the form of clitics. There are clitics in the form of personal pronouns and in the form of particles.

Clitics derived from personal pronouns consist of familiar pronouns and honorific pronouns. The clitics can function as affirmations. In addition, clitics can be accompanied by time markers that contain different meanings. There is a meaning of workings that have been done (perfective), work in progress (presentive), and works to be done (perfective). Clitics that have different functions can be attached to the class of nouns, 
verbs, adjectives, numerals by carrying different meanings according to the context of the speech. Understanding the presence of clitic and time markers in communicating will make it easier for language users, both from around South Sulawesi and from abroad to adapt to the Makassar ethnic community.

\section{REFERENCES}

[1] Spolsky, B. (2003). Sociolinguistics. Oxford: University Press.

[2] Rahardi. K. (2010). Kajian Sosiolinguistik. Bogor: Ghalia Indonesia.

[3] Wahid, S. (2008). Manusia Makassar. Makassar: Pustaka Refleksi.

[4] Davies. A (2004). The Handbook of Applied Linguistics. British: Blackwell Ltd.

[5] Verhaar, J.w.M. (1988). Pengantar Linguistik Umum. Yogyakarta: Gadjah Mada University Press.

[6] Abbas, Asriani. (2014) Perilaku Morfosintaksis Verba Bahasa Makassar. Dissertation on the Post Graduated of Universitas Hasanuddin, Makassar. 